\title{
Shame, Vulnerability and Belonging: Reconsidering Sartre's Account of Shame
}

\author{
Luna Dolezal ${ }^{1}$
}

Published online: 6 June 2017

(C) The Author(s) 2017. This article is an open access publication

\begin{abstract}
Through positing that our capacity for physical vulnerability is at the core of original shame, Sartre's account in Being and Nothingness reveals shame as an essential structure of human existence. Reading Sartre's ontological account of 'pure shame' alongside recent writing about shame in early child development, particularly Martha Nussbaum's account of 'primitive shame,' this article will explore the inherent links between shame, the body and vulnerability, ultimately positing that our human need for belonging is the fundamental driving force behind shame, and what gives it its ontological status. In short, this article will argue that shame is not merely about a painful awareness of one's flaws or transgressions with reference to norms and others, but about a deeper layer of relationality through our bodily vulnerability.
\end{abstract}

Keywords Shame $\cdot$ Vulnerability $\cdot$ Belonging $\cdot$ Embodiment $\cdot$ Jean-Paul Sartre · Martha Nussbaum

\section{Introduction}

Shame has received much attention in recent philosophical scholarship. It has been posited by various thinkers that shame has a central role to play in subject formation, in the constitution of intersubjective relations and crucially in the social politics of inclusion and exclusion. Philosophers working in the phenomenological tradition have positioned shame as central to the ontology of human existence, arguing that without shame certain capacities of consciousness and intersubjectivity would not be possible. In particular, it is argued that, without shame, we would not

Luna Dolezal

L.R.Dolezal@exeter.ac.uk

1 University of Exeter, Amory Building, Office A326, Rennes Drive, Exeter EX4 4RJ, UK 
have the capacity for reflective self-awareness nor eventually become relational or political subjects. As such, shame is theorised as an ontological structure, central to the constitution of subjectivity and intersubjectivity.

Within the phenomenological tradition, recent shame theory has drawn on JeanPaul Sartre's classical account in Being and Nothingness to demonstrate that shame is central to relational subject formation. In particular, recent writing by Dan Zahavi and Lisa Guenther draw explicitly on Sartre to illustrate shame's structural and ontological significance with respect to self and other relations (see Zahavi 2014: 208-240; Guenther 2011). Guenther discusses Sartre's account of shame to demonstrate that an "inescapable relationality" (2011: 37; see also Zahavi 2014: 213) is at the heart of the self and that this relation involves an "embodied entanglement" (2011: 37) that reveals that we are "vulnerable and exposed" (2011: 27). Zahavi, on the other hand, does not claim that shame is a necessary condition of possibility of interpersonal selfhood, ${ }^{1}$ but nonetheless draws on Sartre to demonstrate that "certain forms of self (-experience) are constitutively dependent upon others" (2014: 237). Like Guenther, Zahavi posits shame as revealing our "vulnerability" and "exposure" before others (2014: 235). While both Zahavi and Guenther posit embodied vulnerability as central to shame experiences, and therefore at the heart of (inter)subjective constitution, neither of their accounts develops this claim in relation to Sartre's phenomenological ontology.

In this article, I will address the idea that embodied vulnerability is revealed through shame and, furthermore, is at the heart of subjective constitution. I will extend Zahavi's and Guenther's engagement with Sartre's account of shame by positing that physical vulnerability and the concomitant need for belonging characterise a constitutional aspect of human subjects. Through reading Sartre's phenomenological account of shame alongside developmental literature and Martha Nussbaum's writing on primitive shame, I will extend contemporary philosophical analyses of shame, arguing that what gives shame its significance is the human need for connections to others through the physical body, or what we can understand as a form of primary belonging. While belonging is a multifaceted concept that can signify an wide range of experiences (for instance, how one feels connected to others, to place, to communities, to political structures, social organizations, ancestries, among others), my aim in this work is to discuss the experience of belonging as a sense of connection to others that is embodied and that, furthermore, alleviates anxieties about physical vulnerability. I contend, following the developmental psychology literature, that shame originates from our embodied vulnerability and serves to help us maintain the social bonds necessary for our (physical, emotional, psychological and social) survival.

My account will entail a re-reading of the classical phenomenological account of shame offered by Jean-Paul Sartre. In Being and Nothingness, Sartre initially suggests that both shame and pride have ontological significance, bringing with them the capacity to reveal myself to myself through 'the look' of the other,

\footnotetext{
1 It should be noted that Zahavi posits a minimal pre-social dimension of the self as ontologically prior to the social and inter-personal self that is revealed within shame experiences. While I am drawing on Zahavi's account of shame, I do not follow his argument regarding the minimal self and a fuller consideration of the implications of his arguments is beyond the scope of this article (see Zahavi 2014).
} 
awakening self-reflective awareness. ${ }^{2}$ However, quickly pride is left aside in this account and Sartre focuses his attention on shame, discussing, as I will detail below, shame across three levels. First, he discusses shame as a moral emotion; it is an experience, akin to guilt, where the judgement of others can teach me that I have transgressed some rule or norm. Second, shame is a mode of self-evaluation; through shame I can see and judge myself. Third, and most significantly for this analysis, shame is an ontological structure of subjectivity and intersubjectivity; it is because of our "original shame" (2003: 312), for Sartre, that we have the capacity for reflective self-consciousness and, further, the capacity to be relational subjects.

Sartre's account of ontological shame has been sharply criticized. It has been argued that placing shame at the heart of the structure of human subjectivity and intersubjectivity is a sign of Sartre's general pessimism and a further symptom of his overall negative charactization of human relations as unending struggle and conflict. However, in this article I would like to offer an alternative, and more positive, reading of Sartre's account of shame. In effect, I will suggest that through positing that the body and our physical vulnerability are at the core of original shame, Sartre's account does in fact reveal something essential to the structure of human existence: the vulnerability at the core of our existence and the concomitant human need for connection to others, or belonging. Rather than conflict, Sartre's account of shame suggests that we strive for connection. Through reading Sartre's ontological account of 'pure shame' alongside recent writing about shame in early child development, particularly Martha Nussbaum's account of 'primitive shame,' I will demonstrate the inherent links between shame, the body and vulnerability. I posit that the fundamental driving force behind shame, and what gives it its ontological status, is our human need for belonging, an aspect of our experience that is fundamental but not flawed. In short, I will argue that shame is not merely about a painful awareness of one's flaws or transgressions with reference to norms and others, but about a deeper layer of relationality through our bodily vulnerability.

\section{What is Shame?}

A standard philosophical analysis of shame characterizes shame as an emotion of self-assessment that causes the subject to feel anxiety at the thought of how he or she is seen and judged by others. ${ }^{3}$ Shame experiences are varied and multiple in their expression and it is commonly argued that shame is closely related to a variety

\footnotetext{
${ }^{2}$ In Being and Nothingness Sartre writes: "It is shame or pride which reveals to me the Other's look and myself at the end of the look. It is shame or pride which makes me live, not know the situation of being looked at" (2003: 284f.). With respect to thinking about the dialectic of shame and pride, I would like to thank Gail Weiss for her discussion of Sartrean shame in her conference presentation "The Shame of Shamelessness" at the "Gender and the Politics of Shame' Workshop at the London School of Economics on 14th November 2015.

3 This characterization of the 'standard philosophical analysis' of shame is offered by J. David Velleman and is intended to encompass the views of several philosophers including John Deigh, Gabrielle Taylor, Roger Scruton, Simon Blackburn and Richard Wollhein (see Velleman 2001: 28-29n).
} 
of other self-conscious emotions. ${ }^{4}$ As a result, 'shame' is often used as an umbrella term to indicate a whole "family of emotions" ranging from "the mildest twinge of embarrassment to the searing pain of mortification" (Nathanson 1992: 19). Shame variants include experiences such as embarrassment, humiliation, chagrin, mortification or feelings of defectiveness (see Dolezal 2015a: 2-5). While shame has many variants that arguably differ in intensity (for example, embarrassment is often theorized to be a 'milder' form of shame ${ }^{5}$ ), it is important to note that shame is generally distinguished in a significant manner from guilt. While, in fact, it is often difficult to clearly delineate shame from guilt in ordinary experience, ${ }^{6}$ as the two are often experienced together, most psychologists and philosophers would agree that shame is structurally different from guilt in a significant way. Namely, while guilt arises where one feels bad about an action or something that one has done, shame is about the person that one is (see for instance Niedenthal et al. 1994). In short, shame is connected to one's core self and identity, it concerns a transgression, fault or flaw that will lead others to think less of who one is (rather than merely what one has done).

For example, Aristotle discusses shame as a "fear of disrepute" (2004: 110) which men feel "before those whom they esteem" (1994: 215). As an experience that involves an awareness of not only oneself, and one's transgression, but also crucially, an awareness of how another, or others, see (and judge) the self, shame is characterized as a fundamentally "self-conscious evaluative emotion" (DraghiLorenz et al. 2001: 270). Self-conscious evaluative emotions, like shame, are asserted to be qualitatively different from more 'primary' or 'basic' emotions, such as sadness, joy, anger and fear. ${ }^{7}$ They involve the ability to compare oneself or one's behaviour with an internalized social norm and respond to the outcome of this evaluation. They further involve the capacity to pay attention to the self as though

\footnotetext{
4 This is reflected in lexical considerations, where, for instance, Aristotle's use of the Greek term aidōs ( $\alpha i \delta \omega \varsigma)$ is most often read as 'shame,' but has been variously translated as 'shame' and 'modesty'. For example, in David Ross's translation of The Nicomachean Ethics aidōs ( $\alpha \hat{i} \delta \omega \varsigma$ ) is translated as 'shame,' whereas J. A. K. Thomson's translation is 'modesty' (see Aristotle 2004: 110, 2009: 104f.). Furthermore, there exists a further ambiguity between 'shame' and 'guilt' (see Grimaldi 1988: 105-108). Aidōs carries a variety of meanings in Ancient Greek texts. It is commonly translated in various ways, for example as: shame; modesty; decency; respect; awe; reverence; veneration; ignominy; and disgrace (see Morwood and Taylor 2002: 8; see also Liddell and Scott 1889: 19).

5 There are several thinkers who argue to this effect, citing embarrassment as merely a 'mild' form of shame (see Kaufman 1993: 24; see also Crozier (1990: 39f.).

6 The difficulty in clearly delineating shame and guilt experiences is reflected in the extensive empirical work on this topic (see, for example Tangney et al. 1996).

7 Complex emotions are distinguished from "basic emotions" which several theorists, such as Paul Ekman and Sylvin Tomkins, have posited as a core group of discrete emotions which are said to be fundamental and indispensible human reactions across all cultures (see Miller 1996: 13). Shame is not usually included amongst the basic emotions and is instead considered to be 'complex'. However, it must be noted that some theorists, such as Darwin and Tomkins, do consider shame to be a primary emotion (see Lewis 1992: 18). There are various schemata for characterizing emotion types and it is beyond the scope or interest of this work to consider which schema has most merit. However, the schema which Michael Lewis employs and which seems to give a relevant distinction for the discussion in the present context, is to consider primary emotions those which do not require self-consciousness and secondary those which do (see 1992: 9, 20).
} 
from the perspective of an external observer (Draghi-Lorenz et al. 2001: 270). Shame, as such, involves reflexive awareness of the self and a necessary triangulation of experience, or to use Guenther's formulation, "a relation between me, myself and the Other" (2011: 26). As a triangular experience, shame is perhaps more accurately to be understood as a "self-other-conscious" emotion (Reddy 2008: 145, cited in Zahavi 2011: 224).

In shame, the subject regards him- or herself as the object of another person's perception and understanding, even if that 'other' is imaginary or absent. Despite shame being commonly associated with visibility, it is normally acknowledged that shame can also be a largely internal experience that can arise when no one else is present. In these cases, shame is a state of self-devaluation; it arises as a result of an internal mechanism of assessment. ${ }^{8}$ The self is exposed to an internalized 'other' who holds the judgements and values against which the subject judges himself or herself. This is the line of argument taken up by Julien A. Deonna, Raffaele Rodogno and Fabrice Teroni in their recent book In Defense of Shame: The Faces of an Emotion (2012). In this work, the authors argue that shame is not dependent on an audience, but instead arises purely because of the experience of being unable "to honour the demands consubstantial with being attached to certain values" (2012: xii). Ultimately, for these authors, the source of shame is one's own thoughts about oneself with respect to values to which one is committed.

However, the definition of shame offered by the authors of In Defense of Shame is so focused on one's own evaluation of oneself and, moreover, is so "cognitively demanding" to use Zahavi's evaluation (2014: 220), that it rules out experiences of by-passed shame, pre-reflective shame, more basic forms of infantile shame and experiences where one feels shame even while fundamentally disagreeing with the values of assessment, while, furthermore, also failing to acknowledge the inherently intersubjective and intercorporeal structure of human experience. Even though shame can arise in one's own eyes, it seems clear that the primary locus of shame is social, as Charles Taylor argues (1985: 264). Values and norms do not appear out of nowhere, they are constituted and continuously modified by relations of embodied social interaction.

As a result, the metaphors of an audience, of being seen and of visibility are instrumental in that they highlight the structural features of shame and give some clues to its phenomenology. I follow Zahavi and Guenther in arguing that shame gets its power because we are radically relational to others; what others think of us and how they treat us matters to us in the most non-trivial way. In fact, as shall be discussed below, it is because others matter to us that shame is part of the structure of our experience. In what follows, I will discuss this double movement of shame through considering our bodily vulnerability: its power to radically render us individuals, while simultaneously arising from and reinforcing our fundamental sociality.

\footnotetext{
${ }^{8}$ Bernard Williams also discusses the issue of whether shame is autonomous, in the sense that it can arise from within without the need of external assessment, or whether shame is purely heteronomous, in the sense that it is only through the eyes (and values) of others that shame arises (see 1993: 82-84).
} 


\section{Jean-Paul Sartre and the Look}

The classical phenomenological account of shame is illustrated by Jean-Paul's Sartre's oft-cited vignette of the voyeur overcome by jealousy kneeling by a keyhole to spy on his lover in Being and Nothingness (2003: 282f.). This vignette forms part of a broader description of the constitution of reflexive self-consciousness through the lived body and intercorporeal relations in Sartre's phenomenological ontology.

Sartre develops his account of the formation of reflexive self-consciousness through his analysis of "the look" (2003: 276). Sartre argues that it is through the encounter with the objectifying gaze of another subject, that I gain awareness of myself. When I am looked at by another, I am reduced to an object that is seen. However, the look for Sartre is not merely about being within the other's perceptual field; it is not a neutral seeing, but rather, it is a value-laden looking which has the power to objectify and causes the subject to turn attention to himself or herself in a self-reflective manner. ${ }^{9}$ As a result, for Sartre, the look is intimately bound to shame.

Before the activation of the look, the subject exists in a pre-reflective state, wholly engaged in his intentional actions. The voyeur vignette is illustrative:

Let us imagine that moved by jealousy, curiosity, or vice I have just glued my ear to the door and looked through a keyhole. I am alone and on the level of a non-thetic self-consciousness. This means first of all that there is no self to inhabit my consciousness, nothing therefore to which I can refer my acts in order to qualify them. They are in no way known; I am my acts and hence they carry in themselves their whole justification. (Sartre 2003: 282f.)

In this example, Sartre describes the subject as pre-reflectively engaged in the act of spying. Engrossed in the act of spying, his acts are simply lived: "My consciousness sticks to my acts, it is my acts" (2003: 283). However, Sartre argues that with the appearance of the other, this state is disrupted:

But all of a sudden I hear footsteps in the hall. Someone is looking at me! What does this mean? It means that I am suddenly affected in my being and that essential modifications appear in my structure ... First of all, I now exist as myself for my unreflective consciousness ... I see myself because somebody sees me. (2003: 284)

The encounter with another, and the subsequent look, confers the relation of "Being-seen-by-another" (Sartre 2003: 281). Sartre argues that once we are captured in the look of another we suddenly separate ourselves from the activity in which we are engaged and see the activity and ourselves as though through the eyes of the other; I become 'visible' to myself, both in that I have awareness of my physical body and that I 'see' myself as though from a distanced perspective. In this way, the look gives me an "outside," as Sartre puts it (2003: 283). I suddenly realize

\footnotetext{
9 I provide a more in-depth analysis of Sartre's accounts of the look and of shame in Chapter 2 of Dolezal (2015a). What follows in this section is a modified and updated version of that account. Furthermore, for a critical discussion of Sartre's account of the Look see Dolezal (2012).
} 
and know that I am a voyeur; that I am spying, and so on. Furthermore, I suddenly know that the other can see all these things about me too. This is what Sartre means when he says that the other "teaches me who I am" (2003: 298). Significantly, for Sartre, this happens through shame: "shame ... is the recognition of the fact that I am that object which the Other is looking at and judging" (2003: 285). He writes, "[s]hame reveals to me that I am this being" that the other sees (2003: 286); shame is "the apprehension of myself as a nature" (2003: 286). Because of shame, I no longer exist in a state of transcendent consciousness, but am now self-conscious and reflexively self-aware. Sartre writes: "Thus the Other has not only revealed to me what I was; he has established me in a new type of being ... I need the Other in order to realize to realize fully all the structures of my being" (2003: 246).

Sartre's account of shame through 'the look' reads, at times, as a straightforward description of self-consciousness and his use of the voyeur vignette as concretely illustrating a common self-evaluative feature of our experience of intersubjectivity: the triangulation of me, myself and the other through shame. Read in this way, Sartre's account of the look is both phenomenological, in that it reveals a structure of our experience, and ontological, in that it reveals part of the structure of our existence (see Webber 2011: 183). To illustrate these phenomenological and ontological structures, Sartre employs the account of 'the look,' and concomitantly shame, as a multilayered metaphor. In some sense, he is being literal: sometimes I do need the other to judge me before I realize something about myself. In these cases, the seeming temporality of Sartre's account, where I start as a self-contained transcendent subjectivity, and am transformed into a self-aware relational being, as a result of the objectifying look of the other, makes some sense.

However, Sartre has been criticized sharply as a result of this sort of reading of his account. Some readers have criticized Sartre for taking a far too advanced level of his analysis of our relations with others, arguing that his analysis of 'the look' does not take into account early aspects of social interaction in child development (in particular see Wider 1999: 196). Others have critiqued Sartre for privileging a naive self-contained subject; as Marjorie Grene points out the voyeur has not "been dropped from heaven to watch and listen at the keyhole" (1971-1972: 32). Of course it seems improbable that the voyeur had no awareness of the nature of his acts prior to undertaking them. Furthermore, other readers have berated Sartre for his general pessimism about social relations, arguing that putting shame and objectification at the heart of intersubjectivity is an unjustifiable negative characterization (Cox 2006: 46f.). But in general, these criticisms seem to arise from a fairly ungenerous reading of Sartre.

In fact, it is clear that Sartre intends his accounts of 'the look' and shame to be much more than a literal description of how we relate to others in intersubjective relations, but to have ontological significance: for Sartre, my very existence depends on the other on the most foundational level. Being-seen-by-another, for Sartre, is a constitutive part of experience. As such, the other is there from the beginning and not added on to a solitary subject at some later stage. However, being-seen-byanother and 'the look' are not merely about the objectifying gaze of the Other; in Being and Nothingness the visual metaphor becomes dislodged from "the convergence of two ocular globes in my direction" (Sartre 2003: 281) and becomes 
about a primary relationality through physical embodiment. As Lisa Guenther notes with respect to Sartre's account, "I am always already in relation to Others, even before I become aware of myself as a separate subject ... the presence of the Other [is] in the midst of my own intimate self-relation" (2011: 27). In short, my beingfor-Others is there from the very start. Furthermore, Sartre's use of shame as exemplary of our relations with others is not merely a sign of his pessimism about social relations, but, as I will discuss below, reveals something about the structure of our existence as vulnerable and embodied beings.

\section{Sartre and Shame}

As a result of placing the experience of having explicit awareness of how the body appears to the judgmental and diminishing gaze of the Other at the heart of his accounts of subjectivity and intersubjectivity, Sartre makes shame central to his analysis. Shame, for Sartre, is inextricably linked to the physical body and is primarily an affective, embodied response: it "is an immediate shudder which runs through me from head to foot without any discursive preparation" (2003: 246). Shame makes me aware of my body because its symptoms (the shudder, the heat of the blush, etc.) are lodged there. However, beyond the symptoms of shame being felt on a physical level, shame, in Sartre's account, also brings thematic awareness to the body. In other words, while shame necessarily occurs through the body and has a necessary physiological manifestation, I can also feel shame about my body. ${ }^{10}$ I suddenly 'see' my body engaged in a particular action or appearing in a particular way: "I am ashamed of myself as I appear to the Other" (Sartre 2003: 246).

Sartre's account of shame is multifaceted and multi-layered. Shame is discussed variously as a moral emotion, an embodied affect, a self-evaluative structure, an intersubjective experience and an ontological category. For the purposes of this discussion, I will differentiate three levels of shame in Sartre's account. ${ }^{11}$ First, he discusses shame as a moral emotion; it is an experience where the judgement of others can teach me that I have transgressed or violated some social norm or moral code. Second, shame is a mode of self-evaluation; through shame I can see and judge myself. Third, and most significantly for this article, shame is an ontological structure of subjectivity and intersubjectivity; it is because of our "original shame," for Sartre, that we have the capacity for reflective self-consciousness and are relational subjects through our embodiment.

Shame initially arises when the other's 'look' reveals to me that I have transgressed some social expectation or norm; this is Sartre's characterization of shame as a moral emotion. The voyeur is overcome by shame in the moment when he hears the footsteps behind him because he knows the act of spying is reprehensible: "shame ... is the recognition of the fact that I am indeed the object

\footnotetext{
${ }^{10}$ For more on the difference between shame as having a physical expression as compared to body shame, or shame that is explicitly about the physical body see Dolezal (2015a: 11f.).

11 These three levels of shame in Sartre's account correspond to my discussion of the three levels of the look (epistemological, self-evaluative and ontological) in Dolezal (2012).
} 
which the Other is looking at and judging" (Sartre 2003: 285). This structure appears in several examples in Being and Nothingness: "I have just made an awkward or vulgar gesture ... Somebody was there and has seen me. Suddenly I realize the vulgarity of the gesture and I am ashamed" (2003: 245). ${ }^{12}$ In these examples, shame is straightforwardly linked to judgment by another person who has witnessed a transgression on my part: "Shame is by nature recognition. I recognize that I $a m$ as the Other sees me" (Sartre 2003: 246). I have done something wrong or inappropriate and I have suddenly become aware of this fact by the presence of another person-this is shame. In these cases, shame arises unexpectedly and suddenly, without any necessary cognitive action, or 'discursive preparation' as Sartre puts it, on my part.

However, it seems that for Sartre shame must also be able to occur when one is alone, and is linked also to how I see myself. The empirical presence of another person is not necessary for shame to occur, as the voyeur example ultimately demonstrates: he hears the footsteps, lifts his head and it turns out that nobody is there. In fact, there are many examples in Sartre's account where the other is merely imagined or possible (there is a rustle in the bushes, or movement in the curtains) (2003: 299). As such, shame is also a self-evaluative experience for Sartre.

However, Sartre does not stop his analysis of shame with moralistic or selfevaluative readings. While there are other self-conscious experiences, such as pride or guilt, that have a similar triangular structure to shame, and can arguably lead to the same self-reflexive didactic moments, Sartre is at pains to give shame a deeper and more symbolic significance. In fact for Sartre, as Guenther argues, shame becomes the "fundamental mood of intersubjectivity" (2011: 26). And Zahavi asserts in his discussion of Sartre's account, "shame rather than merely being a selfreflective emotion, an emotion involving negative self-evaluation, is an emotion that reveals our relationality, our being-for-others" (2014: 214). While guilt and pride reveal and reflect on our actions or deeds, shame, it is argued, reveals our core identity or self. Surpassing the moralistic and self-evaluative aspects suggested by his voyeur example, Sartre argues that shame extends beyond the everyday experience of transgression in intersubjective encounters or in social settings. Sartre calls this 'pure shame' and argues that it arises because I am disgusted or disappointed with the dependency or vulnerability I feel before the other:

Pure shame is not a feeling of being this or that guilty object but in general of being an object; that is, of recognizing myself in this degraded, fixed and dependent being which I am for the Other. Shame is the feeling of an original fall, not because of the fact that I may have committed this or that particular fault but simply that I have 'fallen' into the world in the midst of things and that I need the mediation of the Other in order to be what I am. (2003: 312)

Pure shame for Sartre is ontological, it reveals a structure of our existence. This shame is 'pure' because it is not encumbered by the contingencies of particular

\footnotetext{
12 It is worth noting that while the voyeur example is closely linked to moral transgression and guilt, this example of the 'awkward gesture' is more ambiguous. Katherine Morris discusses this example with respect to shame about clumsiness and ugliness (see 2011: 133f.).
} 
social contexts or norms, it exists irrespective of our behaviour, character or circumstances. This ontological shame, as Sartre conceives it, is a necessary feature of every look and hence a permanent background to reflective consciousness. In this schema, shame that arises as a result of a social transgression in an intersubjective encounter or in a self-evaluative moment are meant to be conceived as examples of a more fundamental relation: the shame of having been rendered an object in the first place. As Zahavi notes in discussing Sartre's account, shame "makes me aware of not being in control and having my foundation outside myself" (2014: 213).

For Sartre, when the body is on display to the Other (particularly in its naked state), the vulnerability of objectification is manifested in the experience of shame. He refers again tellingly to the 'original fall' in Genesis:

Modesty and in particular the fear of being surprised in a state of nakedness are only a symbolic specification of original shame; the body symbolizes here our defenseless state as objects. To put on clothes is to hide one's object-state: it is to claim the right of seeing without being seen; that is, to be pure subject. That is why the Biblical symbol of the fall after the original sin is the fact that Adam and Eve 'know that they are naked.' The reaction to shame will consist exactly in apprehending as an object the one who apprehended my own objectstate. (2003: 312)

In considering this passage, Guenther argues that Sartre's reference to an original fall indicates that the subject's deepest desire is to become "like God," or a being that is pure transcendence, impervious to the objectification of others (2011: 26). However, it is also possible to read Sartre's account of pure shame in this context as concerned with a recognition of our inherent physical dependency or neediness, or with the fact that others matter to us in the most non-trivial way; we fundamentally need them to realize the structures of our being, both psychically and materially. As Sartre repeatedly asserts: 'I need the mediation of the Other in order to be what I am' (2003: 312).

Pure shame as Sartre describes it here seems to be shame about the human condition in general: because we are thrown into the world and because we are vulnerable before others through our bodies. Hence, 'pure shame' is not shame in the sense of self-conscious evaluative emotions, as described above; it is not an affective response to a situation where one has an awareness of the self as failing to meet some social expectations. Nor is pure shame merely shame that is by-passed or repressed. Instead, when Sartre discusses 'shame' ontologically, he intends the term to signify something more fundamental: quite simply, a relation of embodied dependency and vulnerability to the other. As Guenther remarks, "For Sartre ... the lesson of shame is that I have an outside that is vulnerable and exposed, a body that exceeds my own conscious experience" (2011: 27).

Indeed, Sartre is at pains to relate our 'object-state' with the body, and he links pure shame intrinsically to concerns around bodily vulnerability. The other, Sartre notes in his Notebooks for an Ethics is apprehended as a "fragile body" and in this apprehension I know that "I can do violence to him" (1992: 499). Sartre writes: "Through me there is a vulnerability of the Other ... This vulnerability, this finitude is the body. The body for others. To unveil the other in his being-within-the-world is 
to love him in his body" (1992: 501). Nudity, in the passage above, symbolizes this original shame linked intimately to our vulnerable, and ultimately defenseless, physical bodies which strive for connection, belonging or 'love,' to echo Sartre.

\section{The Origins of Shame in Bodily Vulnerability}

It is not surprising that Sartre links the experience of shame so fundamentally with the physical body and our inherent physical vulnerability. In fact, the links between the body, shame and exposure of the physical self have a long cultural and conceptual history. ${ }^{13}$ Shame is etymologically and historically connected with the body and nakedness, particularly the desire to conceal one's nakedness. In the biblical story Genesis, after the fall, Adam and Eve become aware of their naked state and cover themselves because they become ashamed of their nudity (Velleman 2001: 27). In this story, the very origin of humanity is intimately linked with shame about the body. A similar link between shame, sexuality and the body is made in a Greek origin myth as recounted by Aristophanes in Plato's Symposium (see Nussbaum 2004: 182). In this story, human beings were once whole, double-sided, spherical beings. Through this wholeness, they were all-powerful and able to challenge the Gods for control over the universe. In order to cut humans down to size and to create an unbridgeable gulf between the Gods and humans, Zeus used lightening bolts to divide the spherical beings into two, so they walked on two legs and could turn around and face their other halves. Humans were suddenly confronted with their nudity and sexual organs that betrayed their physical vulnerability, need and desire. In this moment, according to this myth, humans became needy, incomplete and insecure, perpetually seeking their once blissful and powerful state of completeness. This, as Aristophanes recounts it, is the origin of love. But it is also the origin of shame. The newly formed humans in this story feel shame about their diminished state and their newfound bodily and emotional vulnerability. This creation myth again positions shame at the origin of human experience (Nussbaum 2004: 182).

The link between shame, nudity and vulnerability is further reflected in the etymology of the word shame. In Ancient Greek, aidoia ( $\alpha i \delta o$ iov), a derivative of aidōs, is a standard Greek word for the genitals (Liddell and Scott 1889: 19), again connoting the reaction of wishing to hide or conceal the physical body (Williams 1993: 78). In English, the word shame comes from a pre-Teutonic word meaning 'to cover' where 'covering oneself' is considered the natural expression of shame. ${ }^{14}$ In addition, the German word for shame, Scham, also refers to the genitals as does the Danish word for labia, skamloeber, which literally translates to the lips of shame (Zahavi 2014: 216).

According to the philosopher Max Scheler, nakedness has been traditionally associated with shame and we seek to cover our sexual organs because they are

\footnotetext{
${ }^{13}$ I also discuss the cultural history of shame and its links to the physical body in Dolezal (2015b). See also Dolezal and Lyons (2017).

14 See the 'shame' entry in the Oxford English Dictionary. Also see Klein (1967: 1430).
} 
symbolic of our basic vulnerability as human beings (see 1987). Our naked bodies reveal our fragility, the fact that we are ultimately biological and, hence, mortal beings. In Western culture, humans have traditionally celebrated their minds, their capacity for reason and their connection to divinity. At the same time they have shunned the flesh, and the animal nature of human life has been denied and repressed. As a result, the body and nudity are symbolically shameful because they disrupt our conviction that we are more than merely animals and reveal our undeniable corporeality: the fact that we are imperfect and mortal, while also sexual beings with bodily desires. Our bodies have physical drives that challenge our rationality, they can get sick, be harmed and will ultimately perish and die. The body symbolizes our vulnerability, neediness, physical desire and ultimately the lack of control we have over our own mortality. Hence the body, especially when it falls ill or fails us, is a powerful source and site of shame.

However, the link between shame and the inherent vulnerability and neediness of the physical body is not simply an expression of our cultural history, nor a feature of relations between self-aware adults, but rather, psychologists argue, is a part the basic developmental story of human beings. In fact, some developmental accounts of shame, which I will discuss here below, give us a means to illustrate Sartre's account of pure shame as foundational to the embodied structure of human existence.

\section{Shame in Child Development: Martha Nussbaum on Primitive Shame}

As many thinkers consider shame to be an experience that requires self-awareness and an ability to perceive what others are thinking, or a basic theory of mind, it is argued that shame is an experience that is unavailable to neonates and very young infants, developing only as children gain the capacity for a particular type of reflexive self-awareness. Michael Lewis offers a developmental model of selfconscious emotions arguing that 'basic' emotions, such as joy, anger and sadness, among others, emerge within the first six to eight months of life and the more complex self-conscious evaluative emotions, such as shame, do not develop until eighteen to thirty-six months (1992: 36-58). However, by putting the emphasis on the capacity for a certain type of self-awareness in shame (the self exposed to itself, coupled with its own negative self-evaluation and a further awareness of external norms, rules and values), Lewis downplays the intersubjective aspect of shame and the fact that shame has its origins in relationality through our bodies. ${ }^{15}$ Furthermore, Lewis's conception of self-awareness leads to a problematic understanding of early intersubjectivity. As Draghi-Lorenz, Reddy and Costall point out in their discussion of Lewis's developmental account, "because infants are not supposed to be capable of the necessary distinction between self and other until they have developed an objective self-awareness, they are also supposedly incapable of experiencing and sharing the emotions of others ... Lewis believes indeed that young infants cannot

\footnotetext{
15 Lewis's developmental model based on the idea of levels of self-awareness has been challenged by Dan Zahavi who also argues that Lewis downplays the importance of sociality (see 2014: 211f.).
} 
engage in interpersonal relationships" (2001: 272). Clearly there are problems with positing that relational self-other-conscious emotions, such as shame, emerge late in child development and are wholly dependent on cognitive capacities regarding objective self-awareness.

In contrast to Lewis's account, other thinkers have posited that basic forms of interpersonal awareness which are present very early on, if not even from or before birth, mean that shame as an affective response (one that does not require any sort of discursive preparation, as Sartre describes it in the quote above) is present in very young infants and forms the foundations for the experiences of shame as a selfconscious evaluative emotion that arise later in life and are connected to social norms. To this end, the philosopher Martha Nussbaum discusses at length the developmental account of 'primitive shame' that arises in early infancy and is intimately connected to embodied relations with caregivers (see 2004: 177-189).

Primitive shame, as Nussbaum theorizes it, begins in preverbal infantile development. It is intrinsically connected to the fact that human beings have a prolonged period of helplessness at the beginning of life. In fact, human infants are thoroughly dependent on others for survival and nourishment. While other animals give birth to newborns that can stand, walk and even outrun potential predators within hours of leaving the womb, human infants are reliant on their caregivers for several years. According to Nussbaum, primitive shame is part of early human experience as a means to manage this helplessness and embodied vulnerability.

For the human infant, according to Nussbaum, "the early drama of its infancy is the drama of helplessness before a world of objects" where the infant is "very weak and very powerless toward things of the greatest importance" (2004: 177). The infant demands fullness and comfort through embodied relations with its caregivers. However the realization of these physical needs and desires are beyond the control of the infant, leading to feelings of frustration, an important part of the developmental process, especially with respect to efforts towards movement and motility. Nussbaum argues, "when an infant realizes that it is dependent on others ... we can therefore expect a primitive and rudimentary emotion of shame to ensue" (2004: 183). Shame, in this account, is defined not as an emotion of negative selfevaluation but instead as "a painful emotion responding to a sense of failure to attain some ideal state" (Nussbaum 2004: 184). In short, the bodily recognition of one's physical dependency, vulnerability and lack of omnipotence manifests as primitive shame.

Empirical work in developmental psychology gives support to Nussbaum's arguments. By positing primitive shame as an experience that signals when relations to others (namely caregivers) are threatened, Nussbaum, like Sartre, puts bodily vulnerability, embodied social bonds and physical dependency at the heart of shame. For infants, when social bonds are withdrawn, bodily survival is threatened. Experiments, such as the still or blank face test, demonstrate that when mothers do not respond to their young babies through movement, facial expressions or speech, these infants attempt to appeal for communication through smiling and gesturing; the infant attempts to reestablish a emotional contact with their caregiver. When this fails, babies start to display signs of distress and avoid eye contact. It becomes quickly evident that there is great distress and unhappiness about their mother's 
unresponsiveness as demonstrated by their bodily behaviour (Trevarthen and Aitken 2001: 9; see also Zahavi 2014: 233).

The sorts of body postures, physical gestures and face expressions manifested by these young infants are correlates of the somatic expressions of shame in adults, such as gaze-avoidance, bodily collapse or contraction and downward head movement or position. As Heidi Maibom has argued, these bodily gestures are most commonly associated with appeasement and submissive behavior in non-human social animals (2010: 578). As a result it has been posited that shame behavior is a form of appeasement behavior; or in other words, withdrawing from social contact, through a bodily withdrawal, is a way to appease the other and attempt to repair or maintain social bonds. In this way, the expression of sad avoidance in young infants, as a result of the still or blank face test, is described by some developmental psychologists as a type of proto-shame or primitive shame (Trevarthen and Aitken 2001: 9). Primitive shame, as an affect, does not require any particular mental content, or particular set of thoughts or understandings, but rather registers as a felt experience, or affect, through the physical body. It arises in infants when they feel their social bonds are threatened, when there is a felt sense of separation and isolation. Hence, shame, as both a signal of distress and of appeasement, is a response that arises in order to repair social bonds and ensure survival.

In fact, Colwyn Trevarthen and Kenneth J. Aitken posit that 'non-basic' relational emotions, like primitive shame, are "fundamental to human consciousness" (2001: 20). Moreover, they are "primary and necessary" in early infancy, contributing to the building of relationships and set the foundation for the "child's entry into the social/cultural world, with all the rational, linguistic, and pragmatic conventions and rituals that world offers" (Trevarthen and Aitken 2001: 20). Hence, primitive shame, in this developmental account, is connected to an awareness of separation from others and a foundational dependency on others, or to return to Sartre, "our defenseless state as objects" (2003: 312) in existing as dependent beings. Early experiences of primitive shame, which are deeply connected to bodily neediness and vulnerability, form the foundation of shame as it is experienced in later life, where a conscious concern about societal expectations drives the desire to maintain human connections. As Nussbaum argues, primitive shame is "an awareness of inadequacy that precedes any learning of social norms ... Later ... it is often felt in connection with a fear of abandonment and ostracism" (2004: 185). In short, primitive shame, as an embodied anxiety regarding the threat of losing the physical bonds of caregivers, transforms into social shame, or an anxiety regarding compromising one's social bonds. Concerns regarding physical survival become transmuted into concerns regarding social survival. ${ }^{16}$

\footnotetext{
16 The psychologist Paul Gilbert, who has written extensively on shame, discusses an evolutionary account of shame, and posits that shame evolved as a means to ensure physical and social survival (see 2007).
} 


\section{Conclusion: Shame, Vulnerability and Belonging}

Understanding shame as intimately connected with bodily vulnerability gives us an alternative means to understand Sartre's account of 'original shame' in Being and Nothingness. Instead of being merely an expression of Sartre's negative account of human relations as characterized by ceaseless objectifying and alienating responses between the self and other, original shame signals something fundamental to human existence. Namely, it reveals our necessary vulnerability with respect to others and our deep human concern to maintain social bonds and feelings of belonging.

Theorizing shame as internally related to bodily vulnerability and our dependency on others yields an alternative emphasis to how we understand shame and, further, a means to assess recent philosophical writings on shame which put the emphasis on the individual. Shame cannot merely be characterized as a "global decrease of self-esteem or self-respect and a painful awareness of personal flaws and deficiencies," as Dan Zahavi initially defines shame in his thoroughgoing analysis of recent shame writings (2014: 210). Nor can it merely be a result of one's own thoughts about oneself with respect to values to which one is committed, as Deonna, Rodogno and Teroni would have it (2012: xii). Instead, I posit that shame is fundamentally about our relations with others and our connection to our social world through our sense of embodied vulnerability and our striving for belonging.

As Bonnie Mann writes with reference to the shame theorist Donald Nathanson, shame is "triggered by a 'sundering of the interpersonal bridge' which occurs when our expectations of belonging or warmth from another are thwarted" (2014: 113). The sense of "being shorn from the herd" (1987: 30), as Nathanson puts it, produces the painful fear of disconnection. In fact, in the case of shame, and its concomitant threat to social bonds, social death and physical death can feel imminently convergent. As Mann writes, a "lethal dislocation looms when one is threatened with the unravelling of one's connection to the world" (2014: 117). Or, as Gehert Piers notes, "behind the feeling of shame stands not the fear of hatred but the fear of contempt which, on an even deeper level of the unconscious, spells fear of abandonment, the death by emotional starvation" (1953: 16, as quoted in Probyn 2005: 3; emphasis in original). In moments of shame, Nathanson argues, we can feel symbolically "at risk of death" (1992: 158). In fact, it is because of our "extreme vulnerability to others (in infancy for all one's needs and in adulthood for one's very sense of identity and worth)" (Mann 2014: 111) that shame experiences form part of the structure of our subjective and intersubjective being.

Through recognizing that bodily vulnerability is at the core of shame, we reveal a further layer of our ontology, namely our deep human need for belonging, an aspect of human existence that remains relatively unthematized on the level of phenomenological ontology. ${ }^{17}$ In fact, what looking at vulnerability and our

\footnotetext{
17 While belonging, as a necessary aspect of human existence, remains relatively unthematized by phenomenologists, there is an extensive literature in psychology, sociology, anthropology, among other disciplines, that describe how our deep human need for belonging forms the foundation for all modes of social interaction. Furthermore, there is extensive literature in evolutionary psychology discussing the human need for belonging and its central place in shaping the concerns and motivations for the embodied subject. Roy Baumeister and Mark Leary argue for what they call the 'belongingness hypothesis' which demonstrates a fundamental human drive to seek out rewarding interactions and establish and maintain
} 
inherent physical dependency on others demonstrates is that we are not discrete beings trying to figure out how we are connected to others. Instead, we are connected to others, and necessarily so, and the task is to articulate the existing structures which are the pre-condition for our necessary relationality. Understood in this way, it seems that shame, alongside vulnerability, must be one of these structures. $^{18}$

Furthermore, looking at more primitive forms of shame and how they relate to bodily vulnerability and our inherent dependency on others addresses a concern articulated by Guenther in relation to Sartre. She writes: "Even if shame does characterize our relation to Others who challenge our freedom, it tells us little about our relations with Others who nurture and support our freedom to the point where an experience of shame is even possible" (2011: 27). If we read Sartre's account of pure shame as making salient the ontological structure of our inherent vulnerability and dependency on others for our being, then his account is precisely illustrative of the nurturing and supportive relations we have with others. Shame is not about the lack of those relations, but instead highlights their centrality through making prominent our ontological need for social bonds and belonging.

Acknowledgements Thank you to Matthew Ratcliffe, and the others who participated in the Work In Progress session at the University of Vienna during my research visit there in November 2015, for reading an early draft of this work and giving me invaluable feedback. Thank you also to the Brocher Foundation for their generous support during my residency in July 2015. Early ideas for this paper were developed during that residency.

Open Access This article is distributed under the terms of the Creative Commons Attribution 4.0 International License (http://creativecommons.org/licenses/by/4.0/), which permits unrestricted use, distribution, and reproduction in any medium, provided you give appropriate credit to the original author(s) and the source, provide a link to the Creative Commons license, and indicate if changes were made.

\section{References}

Aristotle. (1994). The 'Art' of Rhetoric (J. H. Freese, Trans.). Cambridge: Harvard University Press. Aristotle. (2004). The Nicomachean Ethics (J. A. K. Thomson, Trans.). London: Penguin Books. Aristotle. (2009). The Nicomachean Ethics (D. Ross, Trans.). Oxford: Oxford University Press.

\section{Footnote 17 continued}

social bonds with others (see 1995). Having a sense of belonging among other individuals and within a community is in fact a foundational aspect of our beings.

18 These insights regarding vulnerability and shame resonate with insights in the recent work of Judith Butler. In her political writing on writing on mourning and violence, Butler insists on "a common human vulnerability," one that "emerges with life itself" and "precedes the formation of "I" (see 2004: 31). This vulnerability for Butler is also significantly linked to the body and our relationality to others. She argues that "we are, from the start, given over to the other ... by virtue of bodily requirements ... we are vulnerable to those we are too young to know and to judge and hence, vulnerable to violence; but also vulnerable to another range of touch, a range that includes the eradication of our being on the one end, and the physical support for our lives at the other" (2004: 31). Through recognizing our basic dependency on others at the emergence of human life, Butler theorizes vulnerability to be central to human existence. 
Baumeister, R. F., \& Leary, M. R. (1995). The need to belong: Desire for interpersonal attachments as a fundamental human motivation. Psychological Bulletin, 117(3), 497-529.

Butler, J. (2004). Precarious life: The power of mourning and violence. London: Verso.

Cox, G. (2006). Sartre: A guide for the perplexed. London: Continuum.

Crozier, W. R. (1990). Social psychological perspectives on shyness, embarrassment, and shame. In W. R. Crozier (Ed.), Shyness and embarrassment: Perspectives from social psychology. Cambridge: Cambridge University Press.

Deonna, J. A., Rodogno, R., \& Teroni, F. (2012). In defense of shame: The faces of an emotion. Oxford: Oxford University Press.

Dolezal, L. (2012). Reconsidering the look in Sartre's being and nothingness. Sartre Studies International, 18(1), 9-28.

Dolezal, L. (2015a). The body and shame: Phenomenology, feminism and the socially shaped body. Lanham, MD: Lexington Books.

Dolezal, L. (2015b). The phenomenology of shame in the clinical encounter. Medicine, Health Care and Philosophy, 18(4), 567-576.

Dolezal, L., \& Lyons, B. (2017). Health-related shame: An affective determinant of health? Medical Humanities. doi:10.1136/medhum-2017-011186.

Draghi-Lorenz, R., Reddy, V., \& Costall, A. (2001). Rethinking the development of 'Nonbasic' emotions: A critical review of existing theories. Developmental Review, 21, 263-304.

Gilbert, P. (2007). The evolution of shame as a marker for relationship security: A biopsychosocial approach. In J. Tracy, R. Robins, \& J. Tangney (Eds.), The self-conscious emotions: Theory and research (pp. 283-310). New York: Guilford.

Grene, M. (1971-1972). Sartre and the Other. Proceedings and Addresses of the American Philosophical Association, 45, 22-41.

Grimaldi, W. M. A. (1988). Aristotle, Rhetoric II: A commentary. New York: Fordham University Press.

Guenther, L. (2011). Shame and the temporality of social life. Continental Philosophy Review, 44(1), 23-39.

Kaufman, G. (1993). The psychology of shame: Theory and treatment of shame based syndromes. London: Routledge.

Klein, E. (1967). A comprehensive etymological dictionary of the English language. Amsterdam: Elsevier.

Lewis, M. (1992). Shame: The exposed self. New York: The Free Press.

Liddell, H. G., \& Scott, R. (Eds.). (1889). An intermediate Greek-English lexicon. Oxford: Oxford University Press.

Maibom, H. L. (2010). The descent of shame. Philosophy and Phenomenological Research, LXXX(3), $566-594$.

Mann, B. (2014). Soverign masculinity: Gender lessons from the war on terror. Oxford: Oxford University Press.

Miller, R. S. (1996). Embarrassment: Poise and peril in everyday life. New York: The Guilford Press.

Morris, K. J. (2011). The graceful, the ungraceful and the disgraceful. In J. Webber (Ed.), Reading Sartre: On phenomenology and existentialism (pp. 130-144). London: Routledge.

Morwood, J., \& Taylor, J. (Eds.). (2002). Pocket Oxford classical Greek dictionary. Oxford: Oxford University Press.

Nathanson, D. L. (1987). A timetable for shame. In D. Nathanson (Ed.), The many faces of shame (pp. 1-63). New York: The Guilford Press.

Nathanson, D. L. (1992). Shame and pride: Affect, sex and the birth of the self. New York: W. W. Norton and Company.

Niedenthal, P., Tangney, J. P., \& Gavanski, I. (1994). 'If Only I Weren't' Versus 'If Only I Hadn't': Distinguishing shame and guilt in counterfactual thinking. Journal of Personality and Social Psychology, 67, 585-595.

Nussbaum, M. C. (2004). Hiding from humanity: Disgust, shame and the law. Princeton: Princeton University Press.

Piers, G. (1953). Shame and guilt: Part I. In G. Piers \& M. B. Singer (Eds.), Shame and guilt: A psychoanalytic study. Springfield, IL: Charles C. Thomas.

Probyn, E. (2005). Blush: The faces of shame. Minneapolis: University of Minnesota Press.

Reddy, V. (2008). How infants know minds. Cambridge: Harvard University Press.

Sartre, J.-P. (1992). Notebooks for an ethics (D. Pellauer, Trans.). Chicago: The University of Chicago Press. 
Sartre, J.-P. (2003). Being and nothingness: An essay on phenomenological ontology (H. E. Barnes, Trans.). London: Routledge.

Scheler, M. (1987). Person and self-value: Three essays (M. S. Frings, Trans.). Dordrecht: Martinus Nijhoff Publishers.

Tangney, J. P., Miller, R. S., Flicker, L., \& Barlow, D. H. (1996). Are shame, guilt and embarrassment distinct emotions? Journal of Personality and Social Psychology, 70(6), 1256-1269.

Taylor, C. (1985). The person. In M. Carrithers, S. Collins, \& S. Lukes (Eds.), The category of the person. Cambridge: Cambridge University Press.

Trevarthen, C., \& Aitken, K. J. (2001). Infant intersubjectivity: Research, theory and clinical applications. Journal of Child Psychology and Psychiatry, 42(1), 3-48.

Velleman, J. D. (2001). The genesis of shame. Philosophy \& Public Affairs, 30(1), 27-52.

Webber, J. (2011). Bad faith and the other. In J. Webber (Ed.), Reading Sartre: On phenomenology and existentialism (pp. 180-194). London: Routledge.

Wider, K. (1999). The self and others: Imitation in infants and Sartre's analysis of the look. Continental Philosophy Review, 32, 195-210.

Williams, B. (1993). Shame and necessity. Berkeley: University of California Press.

Zahavi, D. (2011). Shame and the exposed self. In J. Webber (Ed.), Reading Sartre: On phenomenology and existentialism (pp. 211-226). London: Routledge.

Zahavi, D. (2014). Self and other: Exploring subjectivity, empathy and shame. Oxford: Oxford University Press. 